\title{
Physiological role of cholecystokinin on postprandial insulin secretion and gastric meal emptying in man. Studies with the cholecystokinin receptor antagonist loxiglumide
}

\author{
M.Fried ${ }^{1}$, W.Schwizer ${ }^{1}$, C. Beglinger ${ }^{2}$, U. Keller ${ }^{2}$, J. B.Jansen $^{3}$ and C. B. Lamers ${ }^{3}$ \\ Departments of Gastroenterology, University Hospitals ${ }^{1}$ Lausanne, and ${ }^{2}$ Basel, Switzerland and ${ }^{3}$ Leiden, The Netherlands
}

\begin{abstract}
Summary. Cholecystokinin was previously proposed to play an important role in the regulation of postprandial insulin secretion either indirectly, by inhibiting gastric meal emptying, or directly, by acting as an incretin promoting the release of insulin. The aim of this investigation was therefore to clarify the role of endogenous cholecystokinin in the regulation of insulin release and gastric emptying applying the highly potent and specific cholecystokinin receptor antagonist loxiglumide. Five healthy volunteers were examined after an overnight fast. Gastric meal emptying was measured by the double indicator technique using a multiple lumen tube in the duodenum and ${ }^{99 m} \mathrm{Tc}$-diethylenetriamine pentaacetate as a meal marker and polyethylene glycol 4000 as a duodenal perfusion marker. Postprandial insulin, C-peptide, cholecystokinin and glucose levels were measured after ingestion of two isocaloric meals of a) Ensure (containing fat, protein and glucose), and b) a pure glucose meal (1.11 mol/l). The meals were given either with an intravenous infusion of loxiglumide $\left(22 \mu \mathrm{mol} \cdot \mathrm{kg}^{-1} \cdot \mathrm{h}^{-1}\right)$ or placebo. The infusion of loxiglumide markedly accelerated the gastric emptying of the mixed meal (area under curve, $5576 \pm 352 \mathrm{~min}$ vs $3498 \pm 109 \mathrm{~min}$; $p<0.001$ ) and the pure glucose meal (area under curve
\end{abstract}

$5662 \pm 537 \mathrm{~min}$ vs $3551 \pm 534 \mathrm{~min} ; p<0.05)$. Simultaneously, loxiglumide induced a more rapid rise in postprandial insulin levels after both meals resulting in significantly higher $(p<0.05)$ insulin levels during the first postprandial hour, but similar insulin levels in the second postprandial hour. Accordingly, we found a close correlation between meal emptying and insulin release $(r=0.748, p<0.01)$. Integrated insulin and C-peptide levels for the whole 2 -h experimental period tended to be higher during loxiglumide infusion, but the difference did not reach statistical significance. Similar plasma glucose levels at all time periods were observed with and without loxiglumide infusion. Higher cholecystokinin levels were measured during loxiglumide infusion after the mixed $(p<0.01)$ and the pure dextrose $(p<0.05)$ meals. We conclude that postprandially released cholecystokinin exerts an important role in the regulation of gastric meal emptying and consecutively the postprandial pattern of insulin release. In contrast, no evidence was found for an insulinotropic role for cholecystokinin in man.

Key words: Cholecystokinin blocker, plasma glucose, insulin, C-peptide, plasma cholecystokinin.
Postprandial plasma insulin and glucose levels are controlled by two major components: a) the gastric emptying rate of ingested nutrients and thus the rate of glucose delivery from the stomach to the duodenum, and b) the potency of glucose to release insulin from the pancreatic Beta cell. Previous studies in man demonstrate that infusion of physiological doses of cholecystokinin (CCK) results in a distinct inhibition of gastric emptying [1, 2]. CCK may therefore exert an important physiological action by regulating insulin release and blood glucose levels indirectly through the retardation of gastric meal emptying in man [3].

Among several other gut factors which have been proposed to act as incretins, thus facilitating the release of insulin [4], CCK has previously been shown to stimulate the release of insulin during intravenous infusion of amino acids [5]. CCK might therefore act as an incretin, an additional action possibly contributing to postprandial glucose homeostasis.

The importance of postprandial released, endogenous CCK on postprandial insulin release and plasma glucose levels in relation to gastric meal emptying in man has not been studied and remains as yet poorly defined. The aim of this study was therefore to clarify the role of endogenous CCK in the regulation of postprandial insulin release and glucose homeostasis in man. For this purpose we employed loxiglumide, a highly potent and specific CCK receptor antagonist [6-11], which is available for use in humans. We evaluated postprandial plasma glucose levels, the release of insulin and $C$-peptide in relation to gastric 


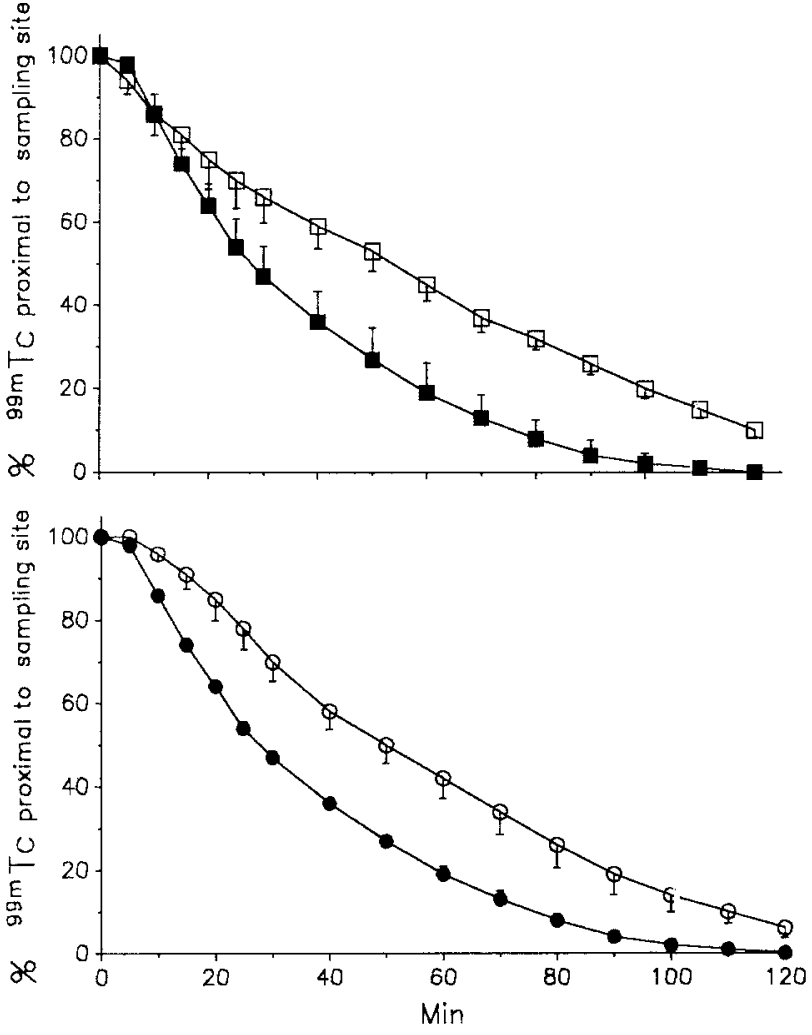

Fig. 1. Gastric emptying ( $\%{ }^{99 \mathrm{~m}} \mathrm{Tc}$ proximal to sampling site) of $500 \mathrm{ml}$ meals of Ensure (circles) or glucose $1.11 \mathrm{~mol} / \mathrm{l}$ (squares) during infusion of placebo (empty symbols) or loxiglumide (filled symbols; $22 \mu \mathrm{mol} \cdot \mathrm{kg}^{-1} \cdot \mathrm{h}^{-1}$ ) in five healthy subjects (mean $\pm \mathrm{SEM}$ )

meal emptying during infusion of loxiglumide or placebo in healthy volunteers.

\section{Subjects and methods}

\section{Experimental design}

Subjects. Five healthy volunteers, 23-51 years old, participated in the experiments. None was taking any medication nor had a history of gastrointestinal symptoms or prior surgery. The studies were approved by the local ethical committee and all subjects gave written, informed consent. All studies were performed after an overnight fast.

Experiments. Each experiment consisted of an 80-min pre-meal period and a 120-min post-meal period. Loxiglumide was given through a separate indwelling intravenous catheter at $22 \mu \mathrm{mol} \cdot \mathrm{kg}^{-1} \cdot \mathrm{h}^{-1}$ the infusion being started $60 \mathrm{~min}$ before meal administration. This dose and time schedule has been previously shown to result in a marked suppression of pancreatic enzyme secretion during intraduodenal perfusion of mixed meals [12]. In control experiments $154 \mathrm{mmol} / \mathrm{l}$ $\mathrm{NaCl}$ was infused instead of loxiglumide.

Two isocaloric $500 \mathrm{ml}$ meals were administered intragastrically: a) a mixed meal, containing fat, protein and glucose (Ensure, $\mathrm{Ab}$ bott, Chicago, Ill., USA) diluted with water, containing $16.2 \mathrm{~g}$ protein, $12.9 \mathrm{~g}$ fat and $51.4 \mathrm{~g}$ carbohydrate per $500 \mathrm{ml}$ and a total caloric value of $387 \mathrm{kcal}, 300 \mathrm{mOsm}, \mathrm{pH} 7$, and b) a pure glucose meal $(100 \mathrm{~g} / 500 \mathrm{ml}, 400 \mathrm{kcal}, 1190 \mathrm{mOsm}, \mathrm{pH} 7)$ were given either with loxiglumide or a placebo infusion $(154 \mathrm{mmol} / 1 \mathrm{NaCl})$. The four tests were performed in all five subjects in strict random order. Only one test was done on each day with a minimum of $48 \mathrm{~h}$ between two experiments in each individual.
Blood sampling. Blood samples were taken through an indwelling venous catheter at $30-\mathrm{min}$ intervals just before each meal and at 10 , $20,30,45,60,90$ and $120 \mathrm{~min}$ after, in ice-chilled ethylenediaminetetraacetic acid tubes that contained 500 Kallikrein Inactivator units aprotinin per $\mathrm{ml}$ of blood. Samples were immediately centrifuged and the plasma stored at $-20^{\circ} \mathrm{C}$ until assay.

\section{Experimental procedure}

Measurement of gastric emptying. Gastric emptying rates were measured by the double indicator technique $[13,14]$. The subjects were intubated with a multiple lumen tube, the tip being placed at the ligament of Treitz. A marker perfusion site was located $20 \mathrm{~cm}$ proximal to the tip at the papilla Vateri. One canal of the tube ended in the antral portion of the stomach. The final position of the tube was verified by fluoroscopy. With the subjects comfortably seated, an infusion of polyethylene glycol 4000 (PEG) $(1.5 \mathrm{~g} \mathrm{PEG} / 100 \mathrm{ml}$ $154 \mathrm{mmol} / \mathrm{l} \mathrm{NaCl}$ ) was commenced through the proximal port of the duodenal tube at a rate of $1.5 \mathrm{ml} / \mathrm{min}$. After allowing $60 \mathrm{~min}$ for equilibration, two pre-meal samples were collected from the tip of the tube at 10-min intervals. The subjects were then given one of the $500 \mathrm{ml}$ liquid meals through the gastric channel, each containing $20-50 \mu \mathrm{Ci}{ }^{99 m} \mathrm{Tc}-$ diethylenetriaminepentaacetate $\left({ }^{99 \mathrm{~m}} \mathrm{Tc}-\mathrm{DTPA}\right)$ as a second non-absorbable marker. Duodenal contents were continuously siphoned as $7-8 \mathrm{ml}$ samples from the distal sampling site, at 5 -min intervals in the first $30 \mathrm{~min}$, and at 10 -min intervals thereafter. At 15-min intervals throughout the experiments, $5 \mathrm{ml}$ samples of gastric contents were collected from the gastric tube, the first sample being taken 5 min after meal ingestion. Duodenal samples were analysed for concentration of PEG [15] and ${ }^{99 \mathrm{~m} T c \text {. Gastric samples }}$ were analysed for ${ }^{99} \mathrm{Tc}$ and PEG. PEG determinations of gastric aspirates proved $P E G$ reflux of the duodenal contents into the stomach to be either lacking or negligible.

Flow rates passing the jejunal sampling site were calculated based on known infusion rates and PEG concentrations at the infusion and sampling ports. The rate of ${ }^{99 m} \mathrm{Tc}$ passage at the distal sampling site was calculated from the product of flow rates and ${ }^{99 \mathrm{~m}} \mathrm{Tc}$ concentrations and was used as an index of gastric emptying. The amount of ${ }^{99_{\mathrm{m}}} \mathrm{Tc}$ proximal to the distal sampling site was calculated by subtracting the cumulative amount of marker recovered at each timepoint from the total amount of marker recovered during the whole experiment at the duodenal sampling site. This amount of ${ }^{99 \mathrm{~m}} \mathrm{Tc}$ marker was expressed as a percentage of the total ${ }^{99_{\mathrm{m}}} \mathrm{Tc}$ recovered during the experiment. Individual emptying curves were plotted using these percentage values. The mean \pm SEM ${ }^{99 \mathrm{~m}} \mathrm{Tc}$ recovery (marker given with the test meals corrected for the amount of ${ }^{99 m}$ Tc aspirated from the stomach) was $86 \pm 5 \%$.

The areas under the emptying curves (AUC; min) were calculated for each individual curve. The emptying curves were furthermore fitted to a power exponential model as described earlier [16].

Radioimmunoassay of insulin, $C$-peptide and CCK. Plasma insulin concentrations $(\mu \mathrm{U} / \mathrm{ml})$ were measured using a commercial RIA kit (CIS Bioindustries, Gif-Sur-Yvette, France) with a sensitivity of $3.6 \mu \mathrm{U} / \mathrm{ml}$. Plasma C-peptide levels ( $\mathrm{pmol} / \mathrm{l}$ ) were measured using antibody 1221 from Novo (Bagsvaerd, Denmark) [17]. Plasma glucose $(\mathrm{mmol} / \mathrm{l})$ was determined by a glucose oxidase technique.

Plasma CCK concentrations were estimated by a sensitive and specific RIA [18]. Antibody T204 binds to all carboxy-terminal specific CCK peptides containing the sulphated tyrosine. The antibody shows $<2 \%$ cross-reactivity to sulphated gastrins and does not bind to unsulphated forms of gastrin nor does it cross-react with structurally unrelated gastrointestinal peptides. Synthetic CCK 8 coupled to ${ }^{125}$ I-hydroxyphenylpropionic acid succinimide ester (Bolton Hunter reagent) was used as standard. All plasma samples were treated by an ethanol extraction procedure. A two-step incubation procedure was used. Separation between free and antibody-bound hormone was performed by a charcoal method. The detection limit of the assay was $0.5 \mathrm{pmol} / 1$. The $50 \%$ inhibition dose was $2.0 \mathrm{pmol} / \mathrm{l}$. The intraassay and interassay variation was 8 and $11 \%$, respectively. 


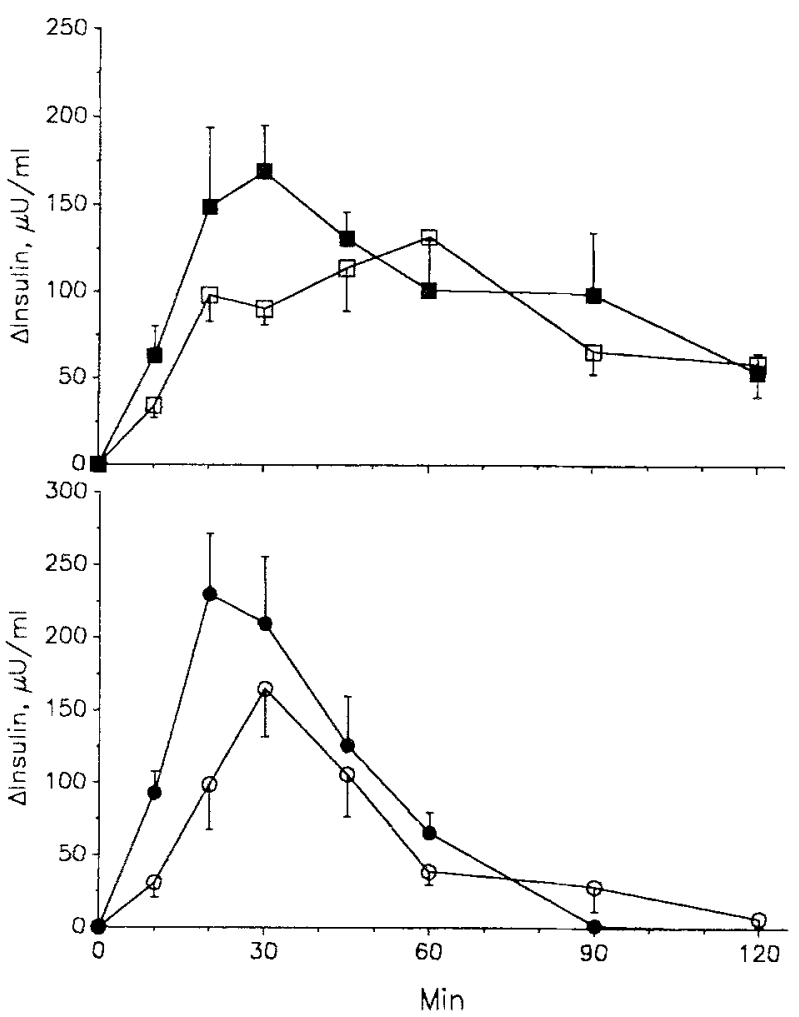

Fig. 2. Plasma insulin levels $(\mu \mathrm{U} / \mathrm{ml})$ after gastric instillation of a mixed meal (Ensure; circles) or glucose 1.11 mol/1 (squares) during infusion of loxiglumide (filled symbols) or placebo (empty symbols) in five healthy subjects (mean \pm SEM)

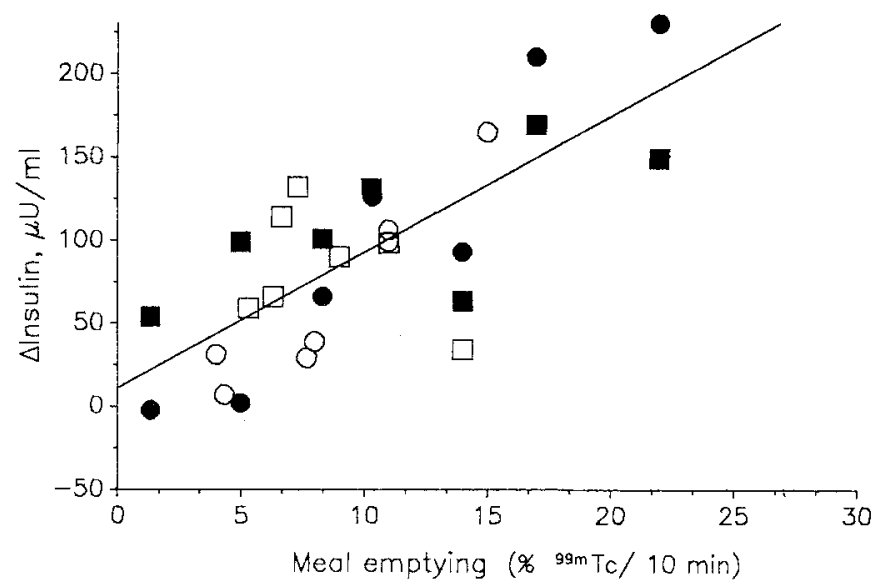

Fig.3. Linear correlation $(\mathrm{y}=10.7+8.2 \times ; r=0.748 ; p<0.01)$ between meal emptying and insulin levels $(\mu \mathrm{U} / \mathrm{ml})$ in five healthy volunteers using single mean timepoints of ${ }^{99 m} \mathrm{Tc}-\mathrm{DTPA}$ recovery (\% recovery/10 $\mathrm{min}$ ) after a mixed (Ensure; circles) and a glucose $1.11 \mathrm{~mol} / \mathrm{l}$ (squares) meal during infusion of loxiglumide (filled symbols) or placebo (empty symbols)

\section{Statistical analysis}

Results are expressed as mean \pm SEM. Increments of insulin, C-peptide, CCK and plasma glucose were computed by subtracting basal values from postprandial levels. The integrated increments of insulin, C-peptide, CCK and plasma glucose were calculated. Responses in experiments with and without infusion of the CCK blocker were compared using a Student's $t$-test for paired values after logarithmictransformation of the data, if appropriate. Linear regression analysis was performed using single timepoints for emptying data and hormone levels. Differences were considered significant if $p<0.05$.

\section{Results}

\section{Gastric emptying}

The mixed meal and the glucose meal were emptied at comparable rates (Fig. 1), both being completely ( > $90 \%$ ) evacuated within $120 \mathrm{~min}$. The infusion of loxiglumide resulted in a marked acceleration of the gastric emptying rates of both meals. Thus, distinctly lower areas under the emptying curves were found during loxiglumide infusion after the mixed meal (AUC $5576 \pm 352 \mathrm{~min}$ vs $3498 \pm 109 \mathrm{~min} ; p<0.001)$ and the pure glucose meal (AUC $5662 \pm 537$ min vs $3551 \pm 534$ min; $p<0.05$ ).

\section{Release of insulin, C-peptide, and CCK}

The infusion of loxiglumide did not alter basal plasma insulin $(4.9 \pm 2.8 \mu \mathrm{U} / \mathrm{ml}$ placebo; $3.4 \pm 0.9 \mu \mathrm{U} / \mathrm{ml}$ loxiglumide, respectively; NS) and plasma glucose (4.9 \pm $0.4 \mathrm{mmol} / \mathrm{l}$ placebo; $4.6 \pm 0.4 \mathrm{mmol} / 1$ loxiglumide, respectively; NS) levels. During loxiglumide infusion insulin concentrations rose more rapidly after both meals resulting in significantly higher integrated insulin levels in the first postprandial hour $(p<0.05)$, but similar insulin levels in the second postprandial hour (Fig.2). Accordingly, we found a close correlation $(r=0.748 ; p<0.01)$ between meal emptying and insulin release in experiments with and without loxiglumide as shown in Figure 3. The mixed meal resulted in maximal insulin levels of $169 \pm 33 \mu \mathrm{U} / \mathrm{ml}$ after 30 min during placebo infusion and $237 \pm 43 \mu \mathrm{U} / \mathrm{ml}$ after 20 min during loxiglumide infusion; after instillation of the glucose meal, insulin levels rose to reach maximal levels of $138 \pm 32 \mu \mathrm{U} / \mathrm{ml}$ after $60 \mathrm{~min}$ during placebo and $173 \pm 26 \mu \mathrm{U} / \mathrm{ml}$ after $30 \mathrm{~min}$ during loxiglumide infusion followed by a continuous decline (Fig. 2). Integrated insulin and C-peptide levels for the whole 2-h experimental period tended to be higher during loxiglumide infusion (Figs. 4 and 5), but the difference did not reach statistical significance.

Similar increases of plasma glucose were observed at all timepoints whether the meals were given with or without loxiglumide infusion (Fig.6). Plasma glucose con-

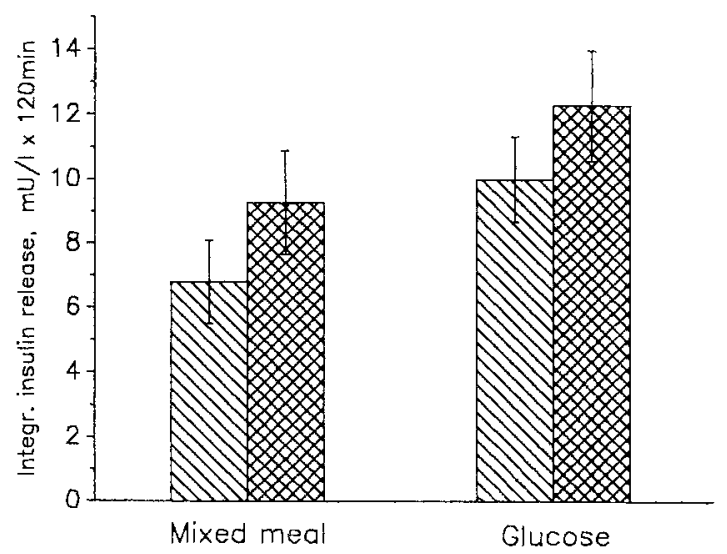

Fig. 4. Integrated plasma insulin levels ( $\mathrm{mU} / \mathrm{A} \times 120 \mathrm{~min})$ after gastric instillation of a mixed meal (Ensure) or glucose $1.11 \mathrm{~mol} / \mathrm{d}$ during the infusion of loxiglumide (cross-hatched bars) or placebo (diagonal bars; mean $\pm \mathrm{SEM} ; n=5$ ) 


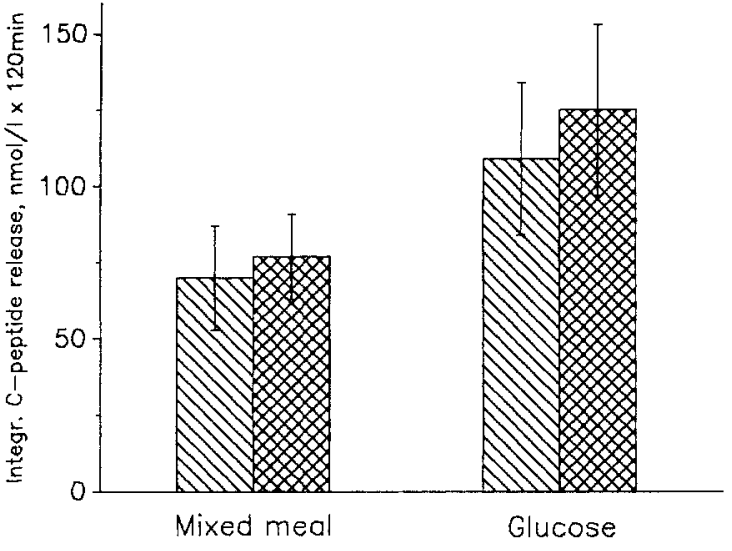

Fig. 5. Integrated plasma C-peptide levels $(\mathrm{nmol} / \mathrm{l} \times 120 \mathrm{~min})$ after gastric instillation of a mixed meal (Ensure) or pure glucose $1.11 \mathrm{~mol} / \mathrm{l}$ during the infusion of loxiglumide (cross-hatched bars) or placebo (hatched bars; mean $\pm \mathrm{SEM} ; n=5$ )

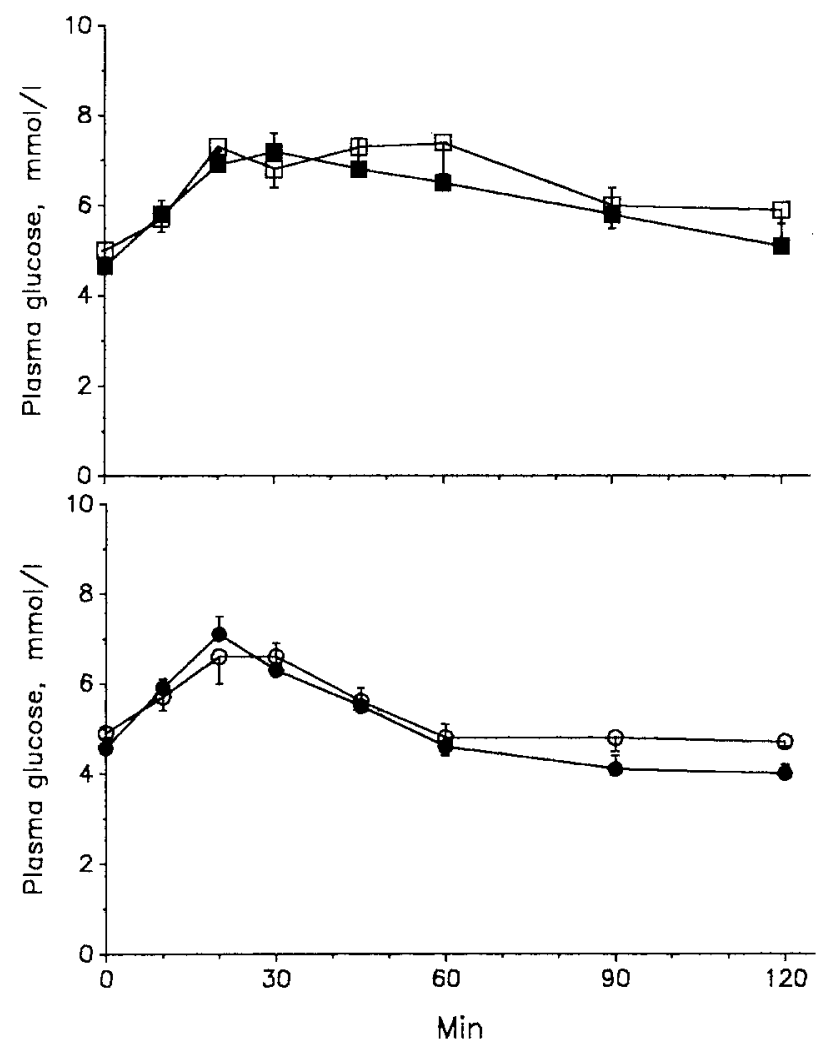

Fig. 6. Plasma glucose concentrations (mmol/l) after intragastric meals of a mixed meal (Ensure; circles) or glucose $1.11 \mathrm{~mol} / \mathrm{l}$ (squares) during the infusion of placebo (empty symbols) or loxiglumide (filled symbols; mean \pm SEM; $n=5$ )

centrations reached a maximum of between 6.9 and $7.3 \mathrm{mmol} / 120 \mathrm{~min}$ after ingestion of the mixed and the pure glucose meal declining thereafter towards basal levels.

Plasma CCK levels (not shown) rose to reach maximal increments within $20 \mathrm{~min}$ of $6.9 \pm 2.6 \mathrm{pmol} / 1$ after the mixed meal and $2.8 \pm 0.6 \mathrm{pmol} / \mathrm{l}$ after the glucose meal, respectively. Higher postprandial CCK concentrations were found during loxiglumide infusion with integrated CCK levels $(\mathrm{pmol} / 1 \cdot 120 \mathrm{~min})$ of $523 \pm 62$ after the mixed meal and $1334 \pm 165$ during loxiglumide infusion $(p<0.001)$; after administration of glucose, integrated CCK release was $230 \pm 69$, and increased to $493 \pm 90$ during loxiglumide infusion $(p<0.05)$.

\section{Discussion}

CCK is an established gut hormone released after food ingestion exerting a major role in the regulation of pancreatic secretion, gallbladder contraction, and gastrointestinal motility [19-22]. Recently we have shown that CCK is the common regulator of gastric emptying and pancreatic secretion [23]. This study suggested a new integrative role of CCK in the upper gastrointestinal tract contributing to the synchronization and coordination of two closely linked functions. As CCK was previously found to influence both gastric emptying $[19,23]$ and insulin release [5] we postulated that CCK might also play an integrative role in the regulation of postprandial glucose homeostasis by controlling both the gastric emptying rate of glucose and the release of insulin.

We found a distinct acceleration of gastric meal emptying during the infusion of the highly potent and specific CCK blocker loxiglumide. Our results confirm previous animal $[8,24-30]$ and human $[19,31]$ studies using loxiglumide and its related compounds proglumide and lorglumide $[8,19,24-27,31]$ as well as other types of CCK antagonists such as MK-329 [28-30] demonstrating a marked acceleration of the gastric emptying rate by CCK blockade. The only two negative studies $[32,33]$ used a solidliquid meal while we employed a liquid meal. As the emptying of the solid and the liquid phase is controlled by different mechanisms [34], it is conceivable that the effect of a CCK antagonist depends upon the type of the meal, probably accounting for the contrasting results.

The faster gastric emptying of both meals during loxiglumide infusion entailed a higher duodenal load of carbohydrates, which was fully compensated for by the augmented release of insulin in the first postprandial hour, explaining similar plasma glucose levels in experiments with and without loxiglumide infusion. Accordingly, we found a close linear correlation between insulin release and meal emptying. The results of this investigation show that CCK regulates insulin release indirectly by controlling the gastric emptying rate and thus the delivery of nutrients to the duodenum. Our results confirm an earlier study demonstrating a dose-dependent retardation of insulin release by intravenous infusion of CCK in physiological doses [3]. We could demonstrate, to our knowledge for the first time, that endogenously released CCK markedly affects the postprandial release pattern of insulin by controlling gastric meal emptying in man. In addition, we found that the effects of endogenously released CCK on the delivery of glucose to the duodenum are fully compensated for by an increased release of insulin early after meal ingestion resulting in relatively uniform plasma glucose levels. These findings explain previous investigations reporting that postprandial blood glucose levels remain regulated within a narrow range, despite wide variations in the content of glucose, fat and protein in the meals $[35,36]$. For example, in one study similar plasma glucose 
levels were observed after ingestion of whole and skimmed milk despite a marked difference in the fat content of the meals [36].

The fact that orally administered glucose evokes a greater insulin response than intravenously administered glucose is well established. Endocrine factors, incretins released from the small gut, are supposed to be responsible for this phenomenon [4]. However, the gut hormone mainly involved has not been as yet clearly determined [37]. Gastric inhibitory polypeptide (GIP) was hitherto considered to be the best candidate incretin [4]. Recent studies, however, have challenged its physiological role as an insulinotropic hormone [38-41] and other peptides such as truncated glucagon-like peptide 1 (GLP 1) have been introduced as new, more potent candidate incretins [42]. In this investigation no reduction of insulin release by $\mathrm{CCK}$ blockade after either a mixed meal or a pure glucose meal was found. Thus, our results do not support a role for CCK as an insulinotropic hormone as reported recently $[5,43]$. One group [5] observed an augmented insulin secretion during a combined infusion of CCK 8 and amino acids, whereas CCK alone had no effect on insulin release. However, it is unclear if a physiological dose of amino acids was applied as no data were presented on postprandial plasma levels of amino acids. For example, no significant rise of plasma amino acid levels after a casein meal was found in a study in rats [43]. In the latter study an incretin effect of CCK was reported by use of the specific CCK antagonist L364798 in response to intraduodenal infusion of casein. Species differences account probably for the contrasting results. Thus, it is known that casein but not albumin is a potent stimulant of $\mathrm{CCK}$ release and pancreatic secretion in the rat [44], whereas albumin markedly releases CCK in man. Our results, excluding a physiological role of CCK as a incretin in man, are confirmed by several preliminary publications applying the CCK antagonist loxiglumide [45-47] and MK-329 [48, 49], where noaugmentation of insulin release by CCK blockade was found.

The infusion of loxiglumide caused a marked increase of plasma CCK levels after both meal types corresponding to a previous study [6]. This phenomenon may be explained by the activation of an enteropancreatic feedback mechanism [50] during CCK blockade resulting in lower duodenal enzyme concentrations. The acceleration of gastric emptying during loxiglumide infusion may have contributed to this phenomenon by accelerating the spread of nutrients over the small intestine and causing an augmented release of CCK.

In summary, by applying the specific and potent CCK receptor antagonist loxiglumide, we could demonstrate, to our knowledge for the first time, that postprandially released CCK exerts a major role in the regulation of gastric meal emptying, and consecutively the postprandial pattern of insulin release. Thus, CCK inhibits gastric meal emptying, simultaneously retarding the release of insulin. In contrast, we found no evidence for a direct insulinotropic role of CCK in man.

Acknowledgements. The study was supported by the Swiss National Science Foundation (32-25727.88). Dr. Schwizer was supported by the Stanley-Johnson-Foundation. Partial support was provided by the Karl-Meyer-Foundation. We thank Dr. Lucio Rovati, Rotta Re- search Laboratories, Monza, Italy for providing loxiglumide and for his suggestions for the preparation of the manuscript.

\section{References}

1. Liddle RA, Morita ET, Conrad CK, Williams JA (1986) Regulation of gastric emptying in humans by cholecystokinin. J Clin Invest 77:992-996

2. Kleibeuker JH, Beekhuis H, Jansen JBMJ, Piers DA, Lamers CBHW (1988) Cholecystokinin is a physiological hormonal mediator of fat-induced inhibition of gastric emptying in man. Eur J Clin Invest 18: 173-177

3. Liddle RA, Rushakoff RJ, Morita ET, Beccaria L, Carter JD, Goldfine ID (1988) Physiological role for cholecystokinin in reducing postprandial hyperglycemia in humans. J Clin Invest 81 : 1675-1681

4. Creutzfeldt W, Ebert R (1986) The enteroinsular axis. In: Go VLW, Gardner JD, Brooks FP, Lebenthal E, DiMagno EP, Scheele GA (eds) The exocrine pancreas. Biology, pathobiology, and diseases. Raven Press, New York, pp 333--346

5. Rushakoff RJ, Goldfine ID, Carter JD, Liddle RA (1987) Physiological concentrations of cholecystokinin stimulate amino acidinduced insulin release in humans. J Clin Endocrinol Metab 65: 395-401

6. Hildebrand P, Beglinger C, Gyr K, Jansen JBMJ, Rovati LC, Zuercher M, Lamers CBHW, Stalder GA (1990) Effects of a cholecystokinin receptor antagonist on intestinal phase of pancreatic and biliary responses in man. J Clin Invest 85: 640-646

7. Setnikar I, Bani M, Cereda R, Chisté R, Makovec F, Pacini MA, Revel L, Rovati LC, Rovati LA (1987) Pharmacological characterization of a new potent and specific nonpolypeptidic cholecystokinin antagonist. Drug Res 37: 703-707

8. Setnikar I, Bani M, Cereda R, Chisté R, Makovec F, Pacini MA, Revel L (1987) Anticholecystokinin activities of loxiglumide. Drug Res 37; 1168-1171

9. Bartho L, Holzer P, Lembeck F, Lippe IT, Setnikar I (1987) Evaluation of a new and potent cholecystokinin antagonist on motor responses of the guinea-pig intestine. Br J Pharmac 90: 753-761

10. Iwamoto Y, Yamamoto R, Kuzuya T (1987) CR-1409 a potent inhibitor of cholecystokinin-stimulated amylase release and cholecystokinin binding in rat pancreatic acini. Pancreas 2: 85-90

11. Makovec F, Bani M, Cereda R, Chisté R, Pacini MA, Revel L, Rovati LA, Rovati C, Setnikar I (1987) Pharmacological properties of lorglumide as a member of a new class of cholecystokinin antagonists. Drug Res 37: 1265-1268

12. Hildebrand P, Beglinger C, Gyr K, Rovati L, Setnikar I, Stalder GA (1988) Pharmacological characterization of a potent cholecystokinin (CCK) antagonist. Gastroenterology 94: 186 (Abstract)

13. MacGregor I, Parent J, Meyer JH (1977) Gastric emptying of liquid meals and pancreatic and biliary secretion after subtotal gastrectomy or truncal vagotomy and pyloroplasty in man. Gastroenterology 72: 195-205

14. Malagelada JR, Longstreth GF, Summerskill WHJ, Go VLW (1976) Measurement of gastric functions during digestion of ordinary solid meals in man. Gastroenterology 70: 203-210

15. Malawer SJ, Owell DW (1967) An improved turbidimetric analysis of polyethyleneglycol utilizing an emulsifier. Gastroenterology $53: 250-256$

16. Elashoff JD, Reedy TJ, Meyer JH (1982) Analysis of gastric emptying data. Gastroenterology 83: 1306-1312

17. Heding L (1975) Radioimmunological determination of human C-peptide in serum. Diabetologia 11: 541-548

18. Jansen JBMJ, Lamers CBHW (1983) Radioimmunoassay of cholecystokinin in human tissue and plasma. Clin Chim Acta 131:305-316

19. Meyer BM, Werth BA, Beglinger C, Hildebrand P, Jansen JBM, Zach D, Rovati LC, Stalder GA (1989) Role of cholecystokinin in regulation of gastrointestinal motor functions. Lancet ii: 12-15 
20. Beglinger C, Fried M, Whitehouse I, Jansen JB, Lamers CB, Gyr K (1985) Pancreatic enzyme response to a liquid meal to hormonal stimulation correlation with plasma secretin and cholecystokinin levels. J Clin Invest 75: 1471-1476

21. Walsh JH (1986) Gastrointestinal hormone. In: LR Johnson (ed) Physiology of the gastrointestinal tract. Raven Press, New York, pp. 181-253

22. Kellow JE, Millder J, Phillips SF, Haddad AC, Zinsmeister AR, Charboneau JW (1987) Sensitivities of human jejunum ileum, proximal colon and gallbladder to cholecystokinin octapeptide. Am J Physiol 252: G345-G356

23. Fried M, Löchner C, Erlacher U, Beglinger C, Jansen J, Lamers C, Stalder GA (1989) Role of CCK in the regulation of gastric emptying and pancreatic secretion in man. Gastroenterology 96 : 159 (Abstract)

24. Shillabeer G, Davison JS (1987) Proglumide a cholecystokinin antagonist increases gastric emptying in rats. Am J Physiol 252: R353-R360

25. Hildebrand P, Beglinger C, Köhler E, Setnikar I, Gyr K (1987) Biological effects of a proglumide derivative as a cholecystokinin antagonist in conscious dogs. Regul Pept 18: 213-220

26. Makovec F, Bani M, Cereda R, Chisté R, Pacini MA, Revel L, Rovati LC (1987) Antispasmodic activity on the gallbladder of the mouse of CR 1409 (lorglumide) a potent antagonist of peripheral CCK. Pharmacol Res Comm 19: 41-51

27. Konturek SJ, Tasler J, Cieszkowski M, Szewczy K, Hladji M (1988) Effect of cholecystokinin receptor antagonist on pancreatic responses to exogenous gastrin and cholecystokinin and to meal stimuli. Gastroenterology 94: 1014-1023

28. Chang RSL, Lotti VJ (1986) Biochemical and pharmacological characterization of an extremely potent and selective nonpeptide cholecystokinin antagonist. Proc Natl Acad Sci 83: 49234926

29. Lotti VJ, Pendleton RG, Gould RJ, Hanson HM, Chang RSL, Clineschmidt BV (1987) In vivo pharmacology of L-364718 a new potent nonpeptide peripheral cholecystokinin antagonist. J Pharmacol Exp Ther 241: 103-109

30. Green T, Dimaline R, Peikin S, Dockray GJ (1988) Action of the cholecystokinin antagonist L364718 on gastric emptying in the rat. Am J Physiol 255: G685-G689

31. Bassi SL, Rovati LC, Giacovelli G, Bolondi L, Barbara L (1990) Effects of loxiglumide a cholecystokinin antagonist in non-ulcer dyspepsia. Gastroenterology 98: 77 (Abstract)

32. Liddle RA, Gertz BJ, Kanayama S, Beccaria L, Coker LD, Turnbull TA, Morita ET (1989) Effects of a novel cholecystokinin (CCK) receptor antagonist MK-329 on gallbladder contraction and gastric emptying in humans. Implications for the physiology of CCK. J Clin Invest 84: 1220-1225

33. Corazziari E, Ricci R, Biliotti D, Bontempo I, De'Medici A, Pallotta N, Torsoli A (1990) Oral administration of loxiglumide (CCK antagonist) inhibits postprandial gallbladder contraction without affecting gastric emptying. Dig Dis Sci $35: 50-54$

34. Meyer JH (1987) Motility of the stomach and gastroduodenal junction. In: Johnson LR (ed) Physiology of the gastrointestinal tract. Raven Press, New York, pp.613-629

35. Tasaka Y, Sekine M, Wakatsuki M, Ohgawara H, Shizume K (1975) Levels of pancreatic glucagon insulin and glucose during twenty-four hours of the day in normal subjects. Horm Metab Res 7:205-206

36. Jenkins DJA, Wolever TMS, Taylor RH, Barker H, Fielden H, Baldwin JM, Bowling AC, Newman HC, Jenkins AL, Goff DV
(1981) Glycemic index of foods, a physiological basis for carbohydrate exchange. Am J Clin Nutr 34:363-366

37. Creutzfeldt W, Ebert R (1985) New developments in the incretin concept. Diabetologia 28: 565-573

38. Sarson DL, Wood SM, Holder D, Bloom SR (1982) The effect of glucose-dependent insulinotropic polypeptide infused at physiological concentrations on the release of insulin in man. Diabetologia 22: 33-36

39. Sarson DL, Wood SM, Kansal PC, Bloom SR (1984) Glucosedependent insulinotropic polypeptide augmentation of insulin physiology or pharmacology? Diabetes 33: 389-393

40. Collier G, McLean A, O'Dea K (1984) Effect of co-ingestion of fat on the metabolic response to slowly and rapidly absorbed carbohydrates. Diabetologia 26:50-54

41. Fried M, Mayer EA, Bloom SR, Taylor IL, Meyer JH (1989) GIP and insulin release in relation to gastric emptying of a mixed meal in man. Regul Pept 26: 305-312

42. Kreymann B, Williams G, Ghatei MA, Bloom SR (1987) Glucagon-like peptide-17-36: a physiological incretin in man. Lancet ii: 1300-1303

43. Rossetti L, Shulman GI, Zawalich WS (1987) Physiological role of cholecystokinin in meal-induced insulin secretion in conscious rats. Studies with L 364718 a specific inhibitor of CCK-receptor binding. Diabetes 36: 1212-1215

44. Green GM, Olds BA, Matthews G, Lyman RL (1973) Protein as a regulator of pancreatic enzyme secretion in the rat. Proc Soc Exp Biol Med 142: 1162-1167

45. Niederau J, Schwarzendrube J, Niederau M, Rüthen R (1990) CCK does not act as a physiologic insulinotropic factor after regular meals in healthy humans. Digestion 46 (Suppl.1): 217 (Abstract)

46. Hildebrand P, Ensinck JW, Mossi S, Delco F, Gyr K, Beglinger C (1990) Cholecystokinin (CCK) is not an incretin in humans. Digestion 46: 57 (Abstract)

47. Bonato C, Valentini A, Tacconi M, Rovati L, Malesci A (1989) Effect of CCK-receptor blockade on the postprandial release of insular hormones. Gastroenterology 96: 51 (Abstract)

48. Liddle RA, Gertz BJ, Kanayama S, Beccaria L, Coker LD, Turnbull TA, Morita ET (1989) Effects of a novel cholecystokinin (CCK) receptor antagonist MK-329 on gallbladder contraction and gastric emptying in humans. Implications for the physiology of CCK. J Clin Invest 84: 1220-1225

49. Liddle RA, Gertz BJ, Kanayama S, Beccaria L, Gettys TW, Taylor IL, Rushakoff RJ, Williams VC, Coker LD (1990) Regulation of pancreatic endocrine function by cholecystokinin: Studies with MK-329 a nonpeptide cholecystokinin receptor antagonist. J Clin Endocrinol Metab 70: 1312-1318

50. Slaff J, Jacobson D, Tilman CR, Curington C, Toskes P (1984) Protease-specific suppression of pancreatic exocrine secretion. Gastroenterology 87: 44-52

Received: 3 April 1991

and revised version: 14 June 1991

Dr. M. Fried

Gastro-entérologie PMU/CHUV

Policlinique Médicale Universitaire

19 , rue César-Roux

CH-1005 Lausanne/Switzerland 